\title{
UBE2O Gene
}

National Cancer Institute

\section{Source}

National Cancer Institute. UBE2O Gene. NCI Thesaurus. Code C150021.

This gene is involved in the monoubiquitination of substrate proteins. 